УДК 378.2

DOI: 10.17277/voprosy.2015.02.pp.085-095

\title{
ORGANIZATION OF FOREIGN POSTGRADUATE TRAINING IN THE REGIONAL UNIVERSITY
}

\author{
E. I. Muratova, E. Yu. Voyakina, A. Yu. Ivanov \\ Tambov State Technical University, Tambov \\ Reviewed by Doctor of Economics, Professor E. S. Mischenko
}

Keywords: academic mobility; foreign postgraduate students; export of educational services; postgraduate school.

\begin{abstract}
The article presents the cause analysis of backwardness in the Russian export market of educational services. It discusses the problems of foreign postgraduate training in Russian universities. The statistical data on the distribution of foreign postgraduate students in Russia and TSTU is provided according to the areas of training. The authors suggest basic ways of increasing the effectiveness of foreign postgraduate training.
\end{abstract}

\section{Introduction}

The export of educational services is becoming an important factor in the development of the modern higher education system in the context of globalization and integration. In Western countries this trend appears one of the priority directions not only in education but also in the country's public policy as a whole. At present the educational policy of many countries is aimed at promoting academic mobility and attracting foreign citizens on training which encourages foreign economic cooperation between these countries, as well as training of specialists at high international level allowing them to compete in the global labor market.

Problems of developing international academic mobility, organizing educational process for foreigners in Russian universities, prospects for employment of such students in Russia and abroad, preferences of foreign students in selecting areas of training, their social adaptation in the foreign environment have been discussed in the works of A. L. Arefyev, V. E. Kishkevich, G. A. Krasnova, V. P. Maksakovskiy et al. [1 - 4]. However

Муратова Евгения Ивановна - кандидат педагогических наук, доцент кафедры «Технологии и оборудование пищевых и химических производств», начальник Управления подготовки и аттестации кадров высшей квалификации; Воякина Елена Юрьевна - кандидат филологических наук, ассистент кафедры «Международная профессиональная и научная коммуникация», начальник отдела аттестации научно-педагогических кадров, e-mail: lenakusa2005@mail.ru; Иванов Александр Юрьевич - специалист по учебно-методической работе, ТамбГТУ, г. Тамбов.

УНИВЕРСИТЕТ им. В.И. ВЕРНАДСКОГО. №2(56). 2015. 
the reforming process of the national education system leads to the necessity to carry out more thorough and detailed analysis of the existing problems in the training of foreign students, including postgraduates, and to find particular ways of solving these problems at the regional level.

The policy of foreign, especially Western, universities is aimed at positioning the country at the international arena, attracting promising young scientists from around the world, promoting languages and disseminating cultural values. Most leading universities make strategic development plans focusing on international training experience and transforming themselves into global scientific and educational complexes.

Many experts say that backwardness in this direction in Russian education is primarily determined by poorly developed strategies in export of educational services in Russia, the incompatibility of Russian and international laws on education, the insignificant share of the joint international educational and research programs, scholarships, grants in foreign languages, as well as various non-academic factors (language barrier, living conditions, level of tolerance in the society, visa regime, financial support, etc.) [5-7]. These problems make it necessary to improve the export system of educational services for Russian universities together with their infrastructure and to take a series of measures aimed at organizing recruitment of foreign students and their preparation in high school.

\section{The overall picture of foreign students' training in Russian postgraduate school}

In recent years the number of foreign students studying abroad has increased significantly. According to statistics, the level of international mobility among students has increased over the last 25 years by $300 \%$. In 2011 the number of students getting education outside their countries amounted up to 2.8 million. And, according to experts, this number will grow to 4.9 million by $2025[8,9]$. The analysis of students' preferences in the choice of the country for education has resulted in the following data. International statistics of the world export market of educational services provides the proportion of foreign students in different countries: in the United States $-21.4 \%$, in the UK $12.6 \%$, in France $-8.8 \%$, in Russia - 2.2\% [10], in other words, major educational centers are in the USA and Western European countries.

After joining the Bologna process Russia is trying to become an active member of the international educational space. For example, there was made the transition on the two-tier system of education, and at the moment we can observe the further development of educational reform in the direction of transforming to the three-tier system: Bachelor - Master - Postgraduate School, which ensures the continuity of the basic educational programs and scientific knowledge, the convertibility of Russian diplomas in the global labor market and, consequently, it allows to facilitate employment of foreign students in different countries.

Among all levels of higher education training of highly qualified personnel, especially foreign citizens, in Russian universities is the most difficult and prestigious form of educational services, and accordingly, it becomes a measure of national science authority abroad and requires consistent 
Table 1

Total number of foreign postgraduate students in Russian universities

\begin{tabular}{l|c|c}
\hline \multirow{2}{*}{$\begin{array}{c}\text { Category } \\
\text { of postgraduate students }\end{array}$} & \multicolumn{2}{c}{ Number of students at the beginning of the year } \\
\cline { 2 - 3 } & Total & Full time students \\
\hline $\begin{array}{l}\text { Foreign postgraduate students } \\
\text { enrolled at the expense of the } \\
\text { federal budget }\end{array}$ & 1768 & 1633 \\
\hline $\begin{array}{l}\text { Foreign postgraduate students } \\
\text { studying under direct contracts } \\
\text { with tuition fees paid by } \\
\text { individuals and (or) legal entities }\end{array}$ & 1313 & \\
\hline $\begin{array}{l}\text { Total number of foreign } \\
\text { postgraduate students }\end{array}$ & 3081 & 1101 \\
\hline
\end{tabular}

and constant increment of scientific knowledge and professional experience. But if we take into account the contingent of foreign students in general (at all levels of higher education), the proportion of foreign postgraduate students is insignificant and makes only $3 \%$ of the total number of postgraduates studying in Russian universities, while in European and American universities the proportion of foreign postgraduates is about $10 \%$. Details on the number of postgraduate students by the end of 2013 according to the Russian Ministry of Education are presented in the following table 1 [11].

Despite the existing problems, the number of foreign postgraduate students in Russia as well as the geography of the countries from which they come from are constantly expanding. To carry out more thorough analysis we will refer to the practice of foreign postgraduate training at Tambov State Technical University.

\section{Characteristics of foreign postgraduate students enrolled at TSTU}

The number of foreign students at the University is 550 people, including postgraduate students - 40 people accounting for $7 \%$ of the total number of foreign students. The change in the number of postgraduates at TSTU for the last five years is shown in Fig. 1.

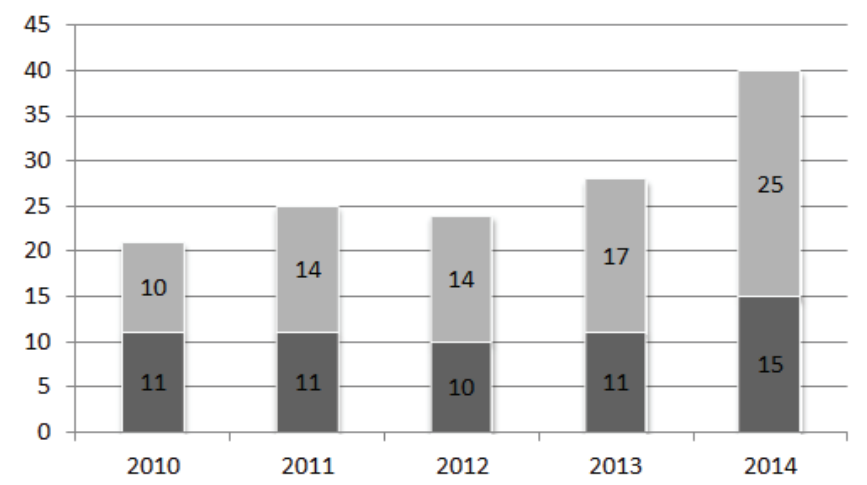

Fig. 1. Dynamics of foreign postgraduate students number at TSTU for the 2010-2014 academic years:

- Budgetary basis; - Contract basis 
The sources of financing of foreign postgraduate training at TSTU are divided into two parts. The first part consists of the state budget funds (funds of national ministries of education, funds received by foreigners in the framework of the exchange transaction "duty - help"). The second part consists of personal funds of sponsors, organizations and enterprises that send postgraduates to study in Russia.

The main inflow of foreign candidates to the Russian postgraduate school, including TSTU, comes from Africa, Asia and the CIS countries. This is due to the lower cost of postgraduate training in Russia in comparison with the training at universities of Western Europe and the United States, as well as to already established relationships in the export of educational services. Currently TSTU has 62 foreign partners; besides, it has concluded research contracts with 11 foreign universities and is realizing 51 educational projects at the moment. To attract new contingent of foreign postgraduates to study at TSTU different strategies are actively used, the most efficient from which are direct international contacts, targeted work with foreign trainees and graduates, interaction with foreign intermediary firms. Distribution of foreign postgraduate students at TSTU by countries of their arrival is shown in Fig. 2.

It should be noted that in recent years the number of postgraduate students by correspondence from Kazakhstan has significantly increased due to the conclusion of the cooperation agreement with the Zhangir Khan West Kazakhstan Agrarian Technical University. In the coming years further increase in the number of foreign students in postgraduate school by correspondence courses can be expected. This growth is likely to come at the expense of immigrants from Russian-speaking families in the CIS countries along with the reduction of opportunities for getting higher education in the Russian language in the national home universities.

The main sources of information about TSTU postgraduate school for foreigners are reviews from those who are studying or have completed studies in the university or from the Ministry of Education of those countries that send their citizens to study in Russian universities. If we talk about the media, advertising and websites of Russian universities, including TSTU, in the opinion of foreign postgraduate students themselves, they are often
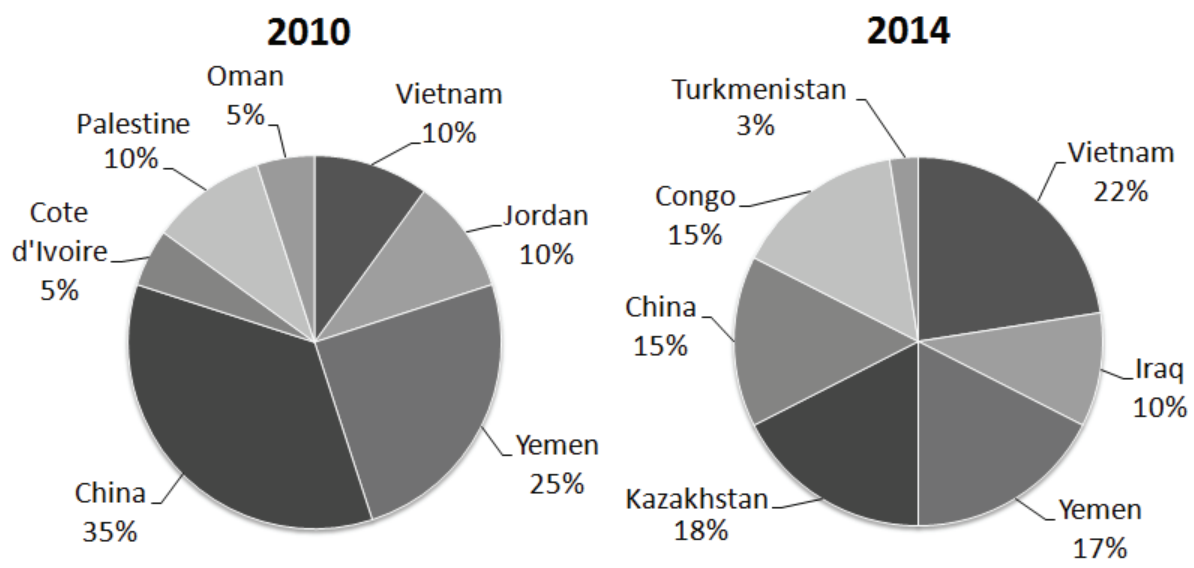

Fig. 2. Distribution of foreign postgraduate students by countries 
uninformative or contain irrelevant information. The possibilities of forming the contingent of foreign postgraduate students through international educational information fairs, Russian cultural centers abroad, Russian institutions within the network of intermediaries abroad are almost not realized (according to experts, from 50 to $80 \%$ of institutions do not use them) [12].

Since TSTU is a technical university, the main choice of training areas preferred by foreign postgraduate students is accounted for engineering, although high priority is also economic sciences. Distribution of foreign postgraduate students by fields of science is shown in Fig. 3.

Among the areas of training in postgraduate school most popular are "Informatics and Computer Engineering" and "Economics". Distribution of foreign postgraduate students by areas of training is given in Table 2.
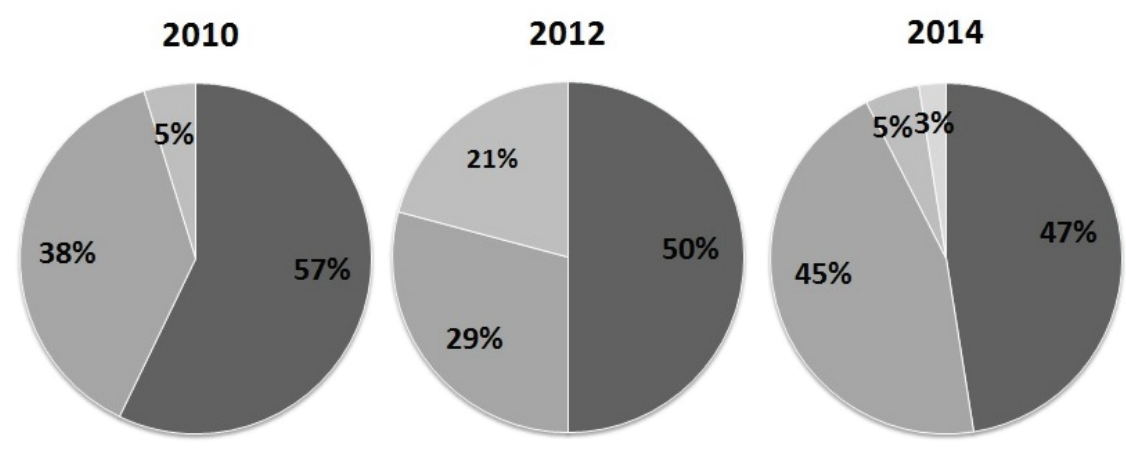

Fig. 3 Distribution of foreign postgraduate students by fields of science:

- Technical; - - Economic; $\square$ - Pedagogical; $\square$ - Political

Table 2

Distribution of foreign postgraduate students by areas of training

\begin{tabular}{l|l|c|c|c}
\hline $\begin{array}{c}\text { Area } \\
\text { of training } \\
\text { code }\end{array}$ & \multicolumn{1}{c|}{ Area of training name } & 2010 & 2012 & 2014 \\
\hline 08.06 .01 & $\begin{array}{l}\text { Machinery and Technology of } \\
\text { Construction }\end{array}$ & - & - & 1 \\
\hline 09.06 .01 & IT and Computer Engineering & 3 & 4 & 8 \\
\hline 12.06 .01 & $\begin{array}{l}\text { Photonics, Instrument Engineering, } \\
\text { Optical Systems and Technologies }\end{array}$ & 1 & 1 & 2 \\
\hline 13.06 .01 & Electricity and Heat Engineering & 1 & 1 & 2 \\
\hline 15.06 .01 & Mechanical Engineering & - & - & 2 \\
\hline 18.06 .01 & Chemical Engineering & 1 & 1 & - \\
\hline 27.06 .01 & Control in Engineering Systems & 6 & 5 & 1 \\
\hline 35.06 .04 & $\begin{array}{l}\text { Technology, mechanization and } \\
\text { power equipment in agriculture, } \\
\text { forestry and fishery }\end{array}$ & - & - & 3 \\
\hline 38.06 .01 & Economics & 8 & 7 & 18 \\
\hline 41.06.01 & Politics and regional studies & - & - & 1 \\
\hline 44.06.01 & Education and pedagogical sciences & 1 & 5 & 2 \\
\hline TOTAL & & 21 & 24 & 40 \\
\hline
\end{tabular}


The SWOT-analysis of foreign postgraduate training and attestation at TSTU conducted by the authors allowed to identify key areas of work aimed at developing the opportunities and strengths of foreign postgraduate students training, as well as at prompt responsiveness to correct current threats and to avoid the emergence of new ones.

\section{The analysis of foreign postgraduate students training at TSTU}

One of the significant external threats in the process of foreign postgraduate recruitment and training in Russian universities is regulatory support in the field of international cooperation. When taking foreigners for studies, Russian universities are faced with legal problems related to noncompliance of Russian legislation and the legislation of the state sending foreigners to study in Russia.

The analysis of the existing regulatory framework for training of foreign citizens in Russia shows that in this area there is a need for additional work to bring the system of training to international standards in accordance with the requirements of the global education market. To eliminate inconsistencies in domestic legislation of the Russian Federation and international agreements, memorandums, conventions it is necessary to consider both national interests of collaborative countries and adherence to international standards and trends.

Another no less important threat is the difficulty of forecasting new admission number of postgraduate students and their distribution by areas of training that is related to the fact that until the last moment there is some uncertainty regarding the arrival of a postgraduate student which is primarily due to the long term paperwork for training abroad, pending the source of funding education, choosing the area of training and the supervisor, etc.

The weakness concerning the problem of a large number of postgraduate students for one supervisor is present not only in training of foreigners. However, working with this category of postgraduates requires much more effort and time costs, while increasing the load of the supervisor.

The process of training foreign postgraduate students is also complicated by the fact that for some postgraduates the main factors of attractiveness of postgraduate training in Russian universities are far from research and are mostly identified with the opportunities to obtain Russian citizenship and lowcost training. In addition, most of foreign postgraduate students having paid tuition fees and defined the topic of their research leave the country returning only at the end of the academic year. Many of them write receipts that they are willing to pay for additional educational courses, but do not attend classes, which leads to non-fulfillment of the individual plan. And if the implementation of postgraduate educational programs in accordance with the federal state requirements was less regulated, the federal state educational standards for the training of highly qualified personnel, introduced in 2014, impose more stringent requirements for the results of mastering educational programs.

Lack of knowledge of the Russian language also prevents the writing of the dissertation, the analysis of the scientific literature, and deep comprehension of the conducted research. However, there is also the opposite edge in knowledge of foreign languages, which makes it possible to get acquainted with foreign scientific periodicals and journals printed in a foreign language. 
Admission of foreign citizens in postgraduate school on area of training which is non-core for technical university in the absence of dissertation councils also creates risks for prompt dissertations defense and reduces the effectiveness of postgraduate school.

However, despite these weaknesses and threats, the overall quantitative indicator of dissertations defense by foreign postgraduates is not lower than that by the Russians, which in turn may be explained by the benefits, which until some time had only foreign postgraduate students, i.e. extension of training for 6 months or one year. The performance of foreign postgraduate students, namely the percentage of dissertations defense in comparison with the graduation number, is shown in Fig. 4.

The most significant reasons for challenges which obstruct the increase of the number of dissertations defense among foreign postgraduate students are: the policy to reduce the number of dissertation councils by the Russian Ministry of Education and Science and the absence at TSTU dissertation councils on new postgraduate programs (specialities of science workers).

Another reason which leads to the deterioration of students' number is connected with the lack of competition among foreign applicants for admission to postgraduate school. Students sent to postgraduate school within the quota shall be enrolled without entrance exams, while admission of foreign citizens in postgraduate school on contractual basis the contest on the results of entrance tests is virtually nonexistent due to the small number of candidates. The impossibility of selecting the "best" candidates inevitably leads to the decrease in the level of training of foreign postgraduate students, their motivation and ability to fulfill the research work. In addition, timing of enrollment to postgraduate school for foreigners is often shifted and they have to catch up with previously enrolled students in the format of external studies or to study by an individual curriculum for the entire period of training in postgraduate school.

As a separate topic, scientific supervision of foreign postgraduate students can be reviewed. The problem of selection and appointment of scientific

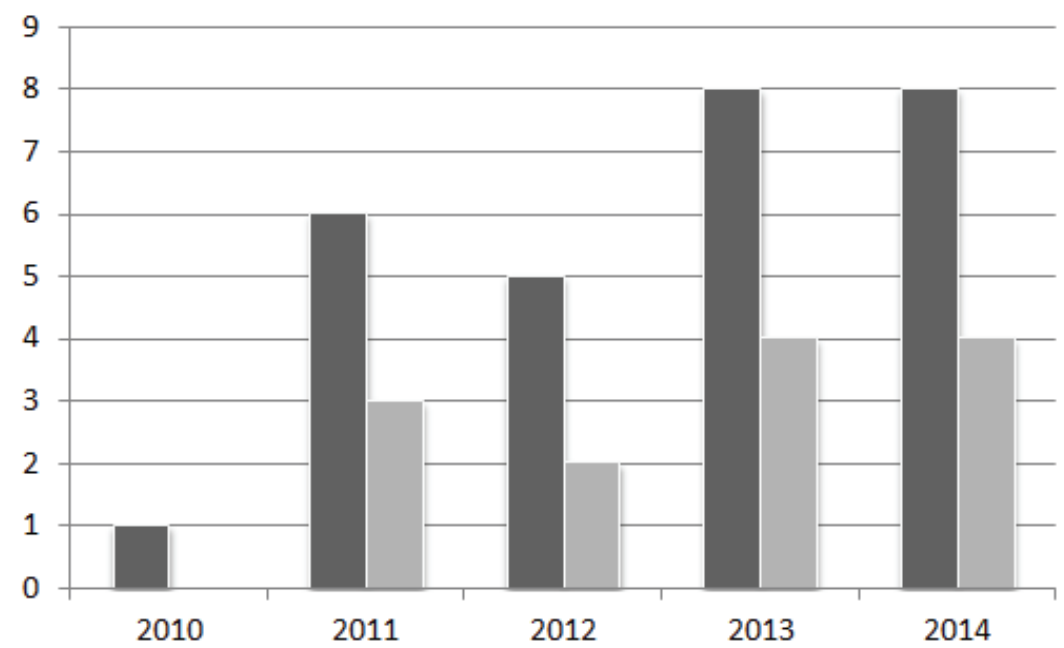

Fig. 4 The number of postgraduate students and dissertation defense by years: - Alumni; - Dissertation defense 
supervisors is a challenge, especially for those postgraduates who received previous education in their home countries and who have a poor command of the Russian language. Another reason is sometimes unproductive work of supervisors with foreign postgraduates due to the fact that most of the supervisors do not speak a foreign language in order to maintain communication on a deeper level in the formulation of dissertation topics, conduct of scientific research, presentation of the results, etc.

To compare the effectiveness of the Russian and foreign postgraduate students' work let us provide the average publication activity on the data presented in the dissertation abstracts for a degree of Candidate of Sciences in dissertation councils of TSTU, speciality 05.11.16 - Information-measuring and operating systems (Industry), 05.25.05 - Information systems and processes, 08.00.05 - Economics and national economy management (management, standardization and product quality control) (Table 3 ).

The analysis of statistical data shows that in almost equal number of scientific publications of Russian and foreign postgraduates, the latter show significantly lower results, i.e. articles in peer-reviewed issues from the list given by Higher Attestation Committee, patents and certificates of computer program registration. Apparently, this is due to simplified approval procedure of dissertations presented by foreign applicants for degrees of Candidate of Sciences in the Higher Attestation Committee. In this regard, supervisors generally impose softer requirements for the dissertations defense submitted by foreign postgraduate students.

To strengthen weak points and eliminate threats in the process of foreign postgraduate students training TSTU is doing constant individual work with postgraduate students, their supervisors and departments they are attached to.

Table 3

\section{Average effectiveness of postgraduate students' research work with dissertation defense in the period from 2010 to 2013}

\begin{tabular}{l|c|c|c|c}
\hline \multirow{2}{*}{$\begin{array}{c}\text { Type } \\
\text { of publication }\end{array}$} & \multicolumn{2}{|c|}{$\begin{array}{c}\text { Dissertation Council } \\
\text { Д 212.260.05 }\end{array}$} & \multicolumn{2}{c}{$\begin{array}{c}\text { Dissertation Council } \\
\text { ДM 212.260.04 }\end{array}$} \\
\cline { 2 - 5 } of RF & $\begin{array}{c}\text { Citizens } \\
\text { of foreign } \\
\text { countries }\end{array}$ & $\begin{array}{c}\text { Citizens } \\
\text { of RF }\end{array}$ & $\begin{array}{c}\text { Citizens } \\
\text { of foreign } \\
\text { countries }\end{array}$ \\
\hline $\begin{array}{l}\text { Total number of } \\
\text { publications }\end{array}$ & 13.07 & 14.16 & 13.74 & 13.34 \\
\hline $\begin{array}{l}\text { Articles in peer- } \\
\text { reviewed issues }\end{array}$ & 3.75 & 3.33 & 4.50 & 3.67 \\
\hline $\begin{array}{l}\text { Articles in other } \\
\text { issues }\end{array}$ & 3.38 & 3.50 & 2.67 & 2.00 \\
\hline Abstracts & 5.81 & 7.33 & 5.57 & 6.67 \\
\hline Monographs & 0.13 & - & 1.00 & 1.00 \\
\hline Patents & 0.31 & - & - & - \\
\hline $\begin{array}{l}\text { Certificates } \\
\text { of computer } \\
\text { program } \\
\text { registration }\end{array}$ & 0.75 & 0.33 & 0.17 & - \\
\hline
\end{tabular}


So, every year there is a special seminar for foreign postgraduates and their supervisors to inform them about the organization of educational and scientific activities during the whole period of training and for a specific academic year.

An important resource support for foreign postgraduate students is the University website which is done in foreign languages and creates conditions which help postgraduate students to perform intellectual and creative activities.

Increasing responsibility for postgraduate students and their supervisors to fulfill the individual plan, monitor the educational and research work of postgraduate students from the part of Department of highly qualified personnel training and attestation, efficient organization of educational process taking into account the individual characteristics of foreign students and coordinated actions by all three parties will allow to achieve the desired outcome.

The necessity to change the process of foreign postgraduate students training is caused by the transition from federal state requirements to federal state educational standards with more regulated procedures for training and attestation. Stricter requirements for the results of mastering postgraduate educational programs are connected with the formation of a clear timetable for the learning process (with a division of the academic year into terms), the introduction of clearly defined examination sessions, including not only qualifying examinations for the degree of Candidate of Sciences, but also exams and tests for other subjects of the curriculum, the introduction of state examination and thesis defense that requires additional effort both from postgraduates, teaching staff and university administration.

\section{Conclusion}

One important factor in ensuring the competitiveness of research and innovation activities of the university is openness and availability of opportunities for quality training of foreign postgraduate students and young scientists, which is based on the principles of productive integration of science and education. Moreover, steps to improve this process should be undertaken not only to postgraduate students (increased requirements to their educational and scientific activities), but also in terms of preparation of local regulations governing the training process of foreign students in postgraduate school, improving the professionalism of the teaching staff as well as the content and organization of educational process, its resource support, the quality of living conditions and safety of foreign students. It is necessary to provide foreign postgraduates the opportunity to participate in international conferences, scientific seminars, forums, workshops, research programs, projects, grants that promote the exchange of achievements in the field of advanced science, engineering and technology. And only the application of these approaches together can improve the efficiency of foreign postgraduate students training, provide an additional inflow of foreigners wishing to study in Russia not only from developing but also from industrialized countries, as well as significantly increase the income of the University from training specialists for foreign countries.

According to the TSTU Development Strategy for the period of $2014-$ 2018 years growth of export of educational services, including the proportion of foreign postgraduates in the total number of students, is an important indicator of the University development. A deliberate policy of the University to expand 
the contingent of foreign students and to improve their educational environment will allow not only to get financial benefits (since most of the foreign students are enrolled on a contractual basis), but also to expand students' social and scientific horizons, to make the image of the University more favorable in the international arena, as well as to raise its international activity indicators in the monitoring held by the Ministry of Education of Russia among all Russian universities.

\section{References}

1. Арефьев, А. Л. Подготовка кадров высшей квалификации для зарубежных стран в российских вузах / А. Л. Арефьев. - М. : Центр социального прогнозирования, 2004. $148 \mathrm{c.}$

2. Кишкевич В.Е., Молофеев В.М. Интернационализация образования и ее роль в повышении качества подготовки специалистов в современном университете / В.Е. Кишкевич, В.М. Молофеев, В.Е. Резников, Л.М. Хухлындина // Вестн. Бурят. гос. университета. Сер. 4. Педагогика. - 2011. - № 2. - С. 127 - 131.

3. Краснова, Г. А. Политика Великобритании и Германии в области экспорта образовательных услуг: опыт и решения / Г. А. Краснова // Унив. управление: практика и анализ. - 2014. - № 2. - С. 50 - 53.

4. Максаковский, В. П. Экономика знаний / В. П. Максаковский. - Смоленск : Универсум, 2012. -104 с.

5. Арефьев, А. Л. Состояние и перспективы экспорта российского образования : монография / А. Л. Арефьев. - М. : РУДН, 2010. - 112 с.

6. Students, Staff and Academic Mobility in Higher Education / Ed. M. Byram, F. Dervin // Cambridge Scholars Publishing. - 2008. - 320 c.

7. Нормативно-правовые акты в области международного сотрудничества [Электронный ресурс] // Российское образования для иностранных граждан. URL : http://russia.edu.ru/information/legal/law/inter/ (дата обращения: 08.09.2014).

8. Mapping Mobility in European higher education. Vol.1: Overview and Trends [Электронный ресурс] / Ed. U. Teichler, I. Ferencz, B. Wachter // Directorate General for Education and Culture, 2011. - URL : http://www.aneca.es/content/download/ 12295/150849/file/Estudio\%20sobre\%20mapeo\%20de\%20movilidad\%20en\%2 0la\%20educacion\%20superior\%20europea.\%20Junio\%202011.Volumen\%20I. English.pdf (дата обращения: 02.11.2014).

9. Гетманова, Г. И. Формирование контингента иностранных учащихся в вузах РФ [Электронный ресурс] / Г. И. Гетманова. - URL : http://www.rciabc.vsu.ru/ irex/pubs/getmanova1.htm (дата обращения: 21.11.2014).

10. Global Education Digest: Comparing Education Statistics Across the World [Электронный ресурс] // UNESCO Institute for Statistics, 2009. - URL : http://www.ifap.ru/library/book433.pdf (дата обращения: 21.10.2014).

11. Статистический сборник о работе в сфере послевузовского профессионального образования в 2013 году (аспирантура и докторантура в системе Минобрнауки России). СПб. : Изд-во Политехн. ун-та, 2014. - 34 с.

12. Российский статистический ежегодник. 2012 : стат. сб. / под ред. А. Е. Суринова, Э. Ф. Баранова, Н. С. Бугакова. - М. : Росстат, 2012. - 786 с.

\section{References}

1. Aref'ev A.L. Podgotovka kadrov vysshei kvalifikatsii dlya zarubezhnykh stran v rossiiskikh vuzakh (Training of highly qualified personnel for foreign countries in the Russian universities), Moscow: Tsentr sotsial'nogo prognozirovaniya, 2004, 148 p. 
2. Kishkevich V.E., Molofeev V.M. Vestnik BGU. Ser. 4. Pedagogika, 2011, no. 2, pp. 127-131.

3. Krasnova G.A. Universitetskoe upravlenie: praktika i analiz, 2014, no. 2 , pp. 50-53.

4. Maksakovskii V.P. Ekonomika znanii (Knowledge economy), Smolensk: Universum, 2012, $104 \mathrm{p}$.

5. Aref'ev A.L. Sostoyanie $i$ perspektivy eksporta rossiiskogo obrazovaniya (Status and prospects of export of Russian education), Moscow: RUDN, 2010, 112 p.

6. Students, Staff and Academic Mobility in Higher Education / Ed. M. Byram, F. Dervin // Cambridge Scholars Publishing, 2008, 320 p.

7. http://russia.edu.ru/information/legal/law/inter/ (accessed 8 September 2014).

8. http://www.aneca.es/content/download/12295/150849/file/Estudio\%20s obre $\% 20$ mapeo $\% 20$ de $\% 20$ movilidad $\% 20$ en $\% 201 \mathrm{a} \% 20$ educacion $\% 20$ superior $\%$ 20europea.\%20Junio\%202011.Volumen\%20I.English.pdf (accessed 02 November 2014). 2014).

9. http://www.rciabc.vsu.ru/irex/pubs/getmanova1.htm (accessed 21 November

10. http://www.ifap.ru/library/book433.pdf (accessed 21 October 2014).

11. Statisticheskii sbornik o rabote v sfere poslevuzovskogo professional'nogo obrazovaniya v 2013 godu (aspirantura i doktorantura v sisteme Minobrnauki Rossii) (Statistical compilation of working in the field of postgraduate education in 2013 (postgraduate and doctoral studies in the Russian Ministry of Education)), SPb.: Izdatel'stvo Politekhnicheskogo universiteta, 2014, 34 p.

12. Surinov A.E., Baranov E.F., Bugakov N.S. et al. (Eds.) Rossiiskii statisticheskii ezhegodnik. 2012: Statisticheskii sbornik (Statistical Yearbook. 2012: Statistical Yearbook), Moscow: Rosstat, 2012, 786 p.

\section{Организация подготовки иностранных аспирантов в региональном университете}

\section{Е. И. Муратова, Е. Ю. Воякина, А. Ю. Иванов}

ФГБОУ ВПО «Тамбовский государственный технический университет», г. Тамбов

Ключевые слова: академическая мобильность; аспирантура; контингент иностранных аспирантов; экспорт образовательных услуг.

Аннотация: Проанализированы причины отставания России на рынке экспорта образовательных услуг. Рассмотрены вопросы организации подготовки иностранных аспирантов в российских вузах. Приведены статистические данные по распределению контингента иностранных аспирантов в России и ТГТУ по направлениям подготовки. Показаны основные пути повышения эффективности подготовки иностранных граждан.

(С) Е. И. Муратова, Е. Ю. Воякина, А. Ю. Иванов, 2015 